\title{
PENGARUH KEPEMIMPINAN TRANSFORMASIONAL DAN IKLIM KERJA TERHADAP PRODUKTIVITAS GURU SMP NEGERI DI KECAMATAN PALMERAH JAKARTA BARAT
}

\author{
Mohamad Najib Anis Subekhi*
}

\begin{abstract}
This study aims to determine the effect of transformational leadership and work climate on teacher productivity State Junior High School in Palmerah Sub-district, West Jakarta. The method used ini this research is survey method with path analysis techniques. This study used a population of teachers State Junior High School in Palmerah Sub-district, West Jakarta much as 200 teachers. Sampling techniques in this study is proportional random sampling methode. Based on the results of the study can be summarized as follows: Firstly, there is the effect of transformational leadership on teacher productivity; Secondly, there is the effect of work climate on teacher productivity; Third, there is the effect of transformational leadership on work climate.
\end{abstract}

Keyword: transformational leadership, work climate, teacher productivity

\section{PENDAHULUAN}

Dalam suatu lembaga pendidikan, pencapaian produktivitas sangat penting, baik produktivitas yang dicapai oleh guru maupun sekolah. Dimensi guru melihat produktivitas dalam kaitannya dengan karakteristik-karakteristik kepribadian guru yang muncul dalam bentuk sikap mental dan mengandung makna keinginan dan upaya guru yang selalu berusaha untuk meningkatkan kualitas pekerjaannya. Sedangkan dimensi sekolah melihat produktivitas dalam kerangka hubungan teknis antara masukan (input) dan keluaran (output). Oleh karena itu dalam pandangan ini, terjadinya peningkatan produktivitas tidak hanya dilihat dari aspek kualitas.

Produktivitas kerja guru merupakan wujud dari pemahaman dan penerapan tentang kompetensi guru, di antaranya kompetensi profesional (Mulyasa, 2008). Guru yang profesional dan produktif dibangun melalui penguasaan sejumlah kompetensi yang secara nyata diperlukan untuk mendukung pelaksanaan tugas pekerjaannya. Kompetensi guru perlu dikembangkan terus menerus sehingga penyelenggaraan pendidikan didukung oleh tenaga pendidik yang profesional dan memiliki kepribadian yang mendukung pelaksanaan tugasnya sehingga menghasilkan guru yang mempunyai produktivitas yang tinggi.

Salah satu masalah pokok yang sering dihadapi oleh sekolah adalah rendahnya produktivitas guru. Berdasarkan data dari Kementerian Pendidikan dan

* Staf Bidang Penatausahaan dan Akuntansi pada Badan Pengelola Keuangan Daerah Pemerintah Kota Tangerang 
Kebudayaan diperoleh informasi bahwa dari sekitar 17,749 guru SMP di DKI Jakarta, 11.35\% memiliki kualifikasi akademik dibawah S1 (Kementerian Pendidikan dan Kebudayaan, Guru berdasarkan Kualifikasi, https:// data.go.id/dataset/guruberdasarkan-kualifikasi/resource/). Data tersebut menunjukkan bahwa, masih ada guru SMP di Jakarta yang belum memenuhi standar akademik. Padahal semakin tinggi tingkat pendidikan guru, maka semakin tinggi pula tingkat kompetensinya yang pada akhirnya produktivitas pun akan meningkat. Sebaliknya, jika pendidikan guru dibawah standar minimal maka akan mengurangi kadar kompetensinya sehingga produktivitas pun menjadi rendah.

Dalam rencana strategis Dinas Pendidikan Provinsi DKI Jakarta 2013-2017 dijelaskan bahwa: Lembaga pendidikan di DKI belum seutuhnya menjadi wahana proses pembentukan sikap dan perilaku ilmiah (learning society) yang selalu siap melakukan perubahan ke arah yang lebih baik. Kemampuan sebagai pendidik dan tenaga kependidikan masih ada yang kurang profesional, kinerja yang masih rendah dan kurang produktif, masih banyaknya tenaga pendidik yang berstatus non PNS dengan tingkat kesejahteraan yang berbeda dengan tenaga pendidik PNS (Renstra, 2013-2017: 43-47).

Secara nasional keterampilan mengajar guru juga masih memprihatinkan. Dari hasil uji kompetensi guru tahun 2015, rata-rata nasional untuk dua bidang kompetensi yaitu kompetensi pedagogik dan kompetensi profesional adalah 53,02 dari standar kompetensi minimum (SKM) yang ditargetkan secara nasional, yaitu rata-rata 55. Jadi, masih belum mencapai target. Hanya 7 (tujuh) provinsi yang telah mencapai nilai SKM UKG. Provinsi tersebut adalah DI Yogyakarta $(62,58)$, Jawa Tengah $(59,10)$, DKI Jakarta $(58,44)$, Jawa Timur $(56,73)$, Bali $(56,13)$, Bangka Belitung $(55,13)$, dan Jawa Barat (55,06) (http://www.kemdikbud.go.id/ main/blog/2016/01/7-provinsi-raih-nilai-terbaik-uji-kompetensi-guru-2015).

Uraian di atas menunjukkan bahwa tingkat produktivitas guru-guru khususnya guru Sekolah Menengah Pertama Negeri di DKI Jakarta diduga masih rendah dan amat bervariatif. Dalam penelitian ini, peneliti memilih memfokuskan penelitian pada Sekolah Menengah Pertama Negeri di Kecamatan Palmerah, Jakarta Barat.

Sekolah Menengah Pertama Negeri di Kecamatan Palmerah, Jakarta Barat, merupakan lembaga pendidikan yang terus berupaya mencapai hasil maksimal di bidang pendidikan. Tetapi, produktivitas guru yang tinggi tidak selalu dimiliki oleh setiap sekolah. Produktivitas guru membutuhkan strategi, tujuan terukur, dan keterpaduan antara perencanaan dan faktor-faktor yang mempengaruhinya. Namun, ada kendala yang menghambat sehingga produktivitas guru pada Sekolah Menengah Pertama Negeri (SMPN) Kecamatan Palmerah, Jakarta Barat saat ini belum maksimal dan belum sesuai dengan tujuan dan arah kebijakan yang tercantum dalam rencana strategis Dinas Pendidikan Provinsi DKI Jakarta.

Rendahnya produktivitas guru disebabkan oleh beberapa faktor, diantaranya adalah gaya kepemimpinan dan iklim kerja. Kepemimpinan transformasional dalam organisasi merupakan gaya kepemimpinan yang mampu mendorong peningkatan 
produktivitas. Kepemimpinan transformasional merupakan gaya kepemimpinan yang mampu mentransformasikan organisasi dalam menghadapi perubahan (Setiawan dan Muhith, 2013: 98). Berani mengambil risiko dalam membawa proses perubahan menjadi ciri utama pemimpin transformasional, sehingga ia menjadi pemimpin yang ideal untuk konteks keefektifan organisasi. Sedangkan iklim kerja merupakan atmosfir atau suasana kerja dalam suatu organisasi. Salah satu aspek penting yang mendukung keberhasilan proses pembelajaran guru adalah iklim kerja. Iklim kerja yang kondusif adalah iklim yang benar-benar sesuai dan mendukung kelancaran serta kelangsungan proses pembelajaran yang dilakukan guru.

Sekolah Menengah Pertama Negeri di Kecamatan Palmerah, Jakarta Barat merupakan lembaga pendidikan yang menginginkan kepala sekolah memiliki strategi kepemimpinan yang baik, dan dapat menciptakan iklim kerja sekolah, sehingga mampu meningkatkan produktivitas guru. Berdasarkan hal tersebut, peneliti tertarik meneliti tentang pengaruh kepemimpinan transformasional dan iklim kerja terhadap produktivitas guru SMP Negeri di Kecamatan Palmerah Jakarta Barat.

\section{Produktivitas}

Prokopenko (1987:3) menjelaskan produktivitas sebagai berikut, "productivity is the relationship between the output generated by a production or service system and the input provided to create this output. Thus, productivity is defined as the efficient use of resources - labour, capital, land, materials, energy, information - in the production of various good and services". Produktivitas adalah hubungan antara keluaran yang dihasilkan oleh suatu produksi atau sistem pelayanan dengan masukan yang disediakan untuk menciptakan keluaran. Dengan demikian produktivitas merupakan efisiensi penggunaan sumber daya (tenaga kerja, modal, lahan bahan, tenaga, informasi) dalam memproduksi beragam barang dan jasa. Whitmore sebagaimana dikutip Sedarmayanti (2009:58), mendefinisikan produktivitas sebagai berikut: Productivity is a measure of the use of the resources of an organization and is usually expressed as a ratio of the output obtained by the uses resources to the amount of resources employed. Whitmore memandang bahwa produktivitas sebagai suatu ukuran atas penggunaan sumber daya dalam suatu organisasi yang biasanya dinyatakan sebagai rasio dari keluaran yang dicapai dengan sumber daya yang digunakan.

Dari deskripsi di atas dapat dipahami bahwa pengertian produktivitas memiliki dua dimensi, yakni efektivitas dan efisiensi. Efektivitas merupakan suatu ukuran yang memberikan gambaran seberapa jauh target yang dapat tercapai baik secara kualitas, kuantitas, maupun waktu. Makin besar persentase target tercapai, makin tinggi tingkat efektivitasnya. Efektivitas berorientasi pada keluaran. Sedangkan efisiensi merupakan suatu ukuran dalam membandingkan penggunaan masukan (input) yang direncanakan dengan penggunaan masukan-masukan yang sebenarnya terlaksana. Efisiensi berorientasi pada masukan. 
Teori produktivitas yang telah dijelaskan oleh para ahli di atas bila diaplikasikan dalam aktivitas guru pada lembaga pendidikan maka produktivitas guru merupakan rasio dari hasil kerja dengan waktu yang dibutuhkan untuk menghasilkan lulusan pendidikan baik secara kuantitatif maupun kualitatif, sehingga diperoleh lulusan yang berkualitas sesuai dengan kebutuhan. Roseline (2011:1088) menyatakan bahwa, "a productive teacher is one who is able to improve students' reading and writing skills, work with students with special needs and employs active learning strategies. Also, a productive teacher puts up good teacher performance, achieve high student success rate, achieve general organizational success, ability to manage available human and material resources in the school". Guru produktif adalah guru yang mampu meningkatkan keterampilan siswa dalam hal membaca dan menulis, dapat bekerja dengan siswa yang berkebutuhan khusus dan dapat menerapkan strategi pembelajaran aktif. Juga, seorang guru produktif memiliki kinerja yang baik, mengarahkan siswa untuk mencapai tingkat keberhasilan yang tinggi, mencapai keberhasilan organisasi secara umum, memiliki kemampuan untuk mengelola sumber daya manusia dan material yang tersedia di sekolah. Guru produktif akan menuliskan apa yang dikerjakan dan mengerjakan apa yang dituliskan.

Berdasarkan uraian di atas dapat disintesiskan bahwa produktivitas adalah hasil yang dicapai seseorang dalam melaksanakan suatu pekerjaan yang tertuang dalam tugas pokok dan fungsi dibandingkan dengan kemampuan yang dimilikinya dalam menyelesaikan pekerjaan untuk mencapai tujuan organisasi dengan indikator adalah: (1) efektif mencapai tujuan, (2) efisien memanfaatkan sumber daya, (3) dapat memanfaatkan waktu secara optimal, (4) sesuai dalam menggunakan metode kerja, dan (5) dapat meningkatkan hasil kerja.

\section{Kepemimpinan Transformasional}

McShane dan Von Glinow (2015:344) mendefinisikan kepemimpinan transformasional sebagai berikut, "transformational leadership is a leadership perspective that explains how leaders change teams or organizations by creating, communicating, and modeling a vision for the organization or work unit and inspiring employees to strive for that vision". Kepemimpinan transformasional merupakan suatu perspektif kepemimpinan yang menjelaskan bagaimana seorang pemimpin melakukan perubahan pada kelompok atau organisasi dengan menciptakan, mengkomunikasikan, dan memperagakan visi organisasi atau unit kerja, dan membangkitkan semangat karyawan untuk mengejar visi itu.

Ada empat karakteristik yang harus dimiliki oleh pemimpin transformasional sebagaimana dikemukakan Robbins dan Judge (2013:383) sebagai berikut, "characteristics of Transformational Leaders are (1) Idealized Influence: Provides vision and sense of mission, instills pride, gains respect and trust, (2) Inspirational Motivation: Communicates high expectations, uses symbols to focus efforts, expresses important purposes in simple ways, (3) Intellectual Stimulation: Promotes intelligence, rationality, and careful problem solving, (4) Individualized Consideration: Gives personal attention, treats each employee individually, coaches, advises". Ciri-ciri pemimpin transformasional adalah (1) 
Pengaruh Ideal/Karismatik: memberikan visi dan misi organisasi dengan jelas, menanamkan kebanggaan, memperoleh respek, dan kepercayaan dari karyawannya, (2) Motivasi Inspirasi: mengkomunikasikan harapan yang tinggi, menggunakan berbagai simbol untuk memfokuskan usaha atau tindakan, mengungkapkan tujuan-tujuan yang penting dengan cara yang sederhana, (3) Stimulasi/rangsangan intelektual: meningkatkan kecerdasan dan cara berpikir rasional, dan memecahkan masalah secara hati-hati, (4) perhatian pada setiap individu: memberikan perhatian kepada masing-masing personal, memperlakukan setiap karyawan secara individu, melatih dan menasehati karyawan untuk menjalankan tugas dengan baik.

Colquitt, LePine dan Wesson (2013:475-476) menyatakan tentang kepemimpinan transformasional bahwa, "transformational leadership involves inspiring followers to commit to a shared vision that provides meaning to their work while also serving as a role model who helps followers develop their own potential and view problems from new perspectives". Kepemimpinan transformasional meliputi menginspirasi pengikut untuk berkomitmen terhadap visi bersama yang memberi arti untuk pekerjaan mereka sementara juga sekaligus merangkap sebagai panutan yang membantu pengikut mengembangkan potensi dan melihat masalah mereka sendiri dari perspektif baru. Selanjutnya Kinicki dan Kreitner (2008:359) mengatakan bahwa: "transformational leadership is transforms employees to pursue organizational goals over self interests". Kepemimpinan transformasional adalah kepemimpinan yang mentransformasikan para karyawan untuk mengejar tujuan organisasi di atas kepentingan diri sendiri.

Berdasarkan uraian di atas dapat disintesiskan bahwa kepemimpinan transformasional adalah perilaku seseorang yang berupaya mentransformasikan nilai-nilai yang dianut oleh pengikut untuk mendukung visi dan tujuan organisasi melalui suatu relasi yang empati dan penciptaan iklim yang menyenangkan, sehingga tumbuh saling percaya satu sama lain dengan indikatornya adalah: (1) memiliki kemampuan yang bisa dicontoh; (2) bisa memberikan motivasi inspirasi; (3) mampu memberikan stimulus intelektual; dan (4) memiliki kepekaan individu.

\section{Iklim Kerja}

Serhan A. Al-Shammari (2015:1556) mengatakan bahwa, "the work environment or work climate is the physical location where somebody works". Iklim kerja adalah lokasi fisik di mana seseorang bekerja. Kohun sebagaimana dikutip Taiwo (2010:301), memberikan definisi tentang iklim kerja sebagai: . . " an entirely" which comprises the totality of forces, actions and other influential factors that are currently and, or potentially contending with the employee's activities and performance. Work environment is the sum of the interrelationship that exists within the employees and between the employees and the environment in which the employees work". Iklim kerja merupakan "keseluruhan totalitas" yang terdiri dari totalitas kekuatan, tindakan dan faktor lainnya yang berpengaruh saat ini dan atau berpotensi bersaing dengan kegiatan dan kinerja 
karyawan. Iklim kerja adalah jumlah dari keterkaitan yang ada dalam diri karyawan dan antara karyawan dan lingkungan di mana karyawan bekerja.

Selanjutnya dalam kaitannya dengan iklim kerja di sekolah, Hoy dan Miskel (2013) menjelaskan sebagai berikut, "an Open School Climate is characterized by teacher relations that are professional, collegial, friendly, and committed to the education of students. The principal is supportive and professional and does not restrict or direct teachers with orders. A Closed School Climate is characterized by teacher relations that are disengaged, distant, suspicious, and not professional. The principal is directive, restrictive, and not supportive". Sekolah dengan iklim terbuka ditandai dengan hubungan guru yang profesional, kolegial, ramah, dan berkomitmen untuk pendidikan siswa. kepala sekolah mendukung dan profesional dan tidak membatasi atau guru langsung dengan perintah. Sedangkan sekolah dengan iklim tertutup ditandai dengan hubungan guru yang terlepas, jauh, mencurigakan, dan tidak profesional. Kepala sekolah adalah direktif, membatasi, dan tidak mendukung.

Berdasarkan uraian di atas dapat disintesiskan bahwa iklim kerja adalah kondisi lingkungan kerja atau suasana kerja yang mendukung pegawai dalam pelaksanaan tugas dan pekerjaannya dengan indikatornya adalah: (1) hubungan antar pribadi; (2) penghargaan dan hukuman; (3) fasilitas; (4) kondisi kerja; dan (5) kebijakan.

\section{METODE}

Penelitian ini dilaksanakan di SMP Negeri di Kecamatan Palmerah, Jakarta Barat yang dilaksanakan selama 3 (tiga) bulan. Metode yang dipakai dalam penelitian ini adalah metode survey dan teknik analisis jalur dengan analisis data secara inferensial. Populasi terjangkau dalam penelitian ini adalah semua guru yang bekerja pada Sekolah Menengah Pertama (SMP) Negeri di Kecamatan Palmerah Jakarta Barat, berjumlah 200 orang dengan jumlah sampel sebanyak 133 guru. Data yang dikumpulkan dalam penelitian dijaring melalui kuesioner yang berupa skala penilaian (rating scale) dengan sebaran skor antara 1 sampai dengan 5.

Setelah dilakukan analisis deskriptif dilanjutkan dengan uji persyaratan analisis berupa uji normalitas, uji linearitas data dan keberartian regresi, dilakukan uji hipotesis dengan menggunakan teknik analisis jalur (path analysis).

\section{HASIL DAN PEMBAHASAN}

\section{Pengaruh Kepemimpinan Transformasional terhadap Produktivitas Guru}

Dari hasil pengujian hipotesis pertama dapat disimpulkan bahwa terdapat pengaruh langsung positif kepemimpinan transformasional terhadap produktivitas guru dengan nilai koefisien korelasi sebesar 0,994 dan nilai koefisien jalur sebesar 0,565. Ini memberikan makna kepemimpinan transformasional berpengaruh langsung terhadap produktivitas guru.

Pola hubungan antara kedua variabel ini dinyatakan oleh persamaan regresi $\dot{X}_{3}=116,099+0,139 X_{1}$. Persamaan ini memberikan informasi bahwa setiap perubahan satu unit kepemimpinan transformasional kepala sekolah dapat 
mengakibatkan terjadinya perubahan produktivitas guru sebesar 0,139 pada konstanta 116,099. Hasil analisis korelasi sederhana kepemimpinan transformasional terhadap produktivitas guru sangat tinggi, artinya makin baik kepemimpinan transformasional kepala sekolah, maka makin tinggi produktivitas guru. Demikian pula sebaliknya makin rendah kepemimpinan transformasional kepala sekolah maka makin rendah pula produktivitas guru.

Hasil penelitian ini senada dengan pendapat beberapa ahli diantaranya adalah Hakan (2008:720), "on the other hand, using mostly transformational leadership behaviors may result in positive effects such as high satisfaction and commitment, high motivation and high productivity levels in subordinates". Perilaku kepemimpinan transformasional dapat menghasilkan efek positif seperti Kepuasan dan komitmen yang tinggi, motivasi yang tinggi dan tingkat produktivitas karyawan tinggi. Selanjutnya Dola (2015:12) menambahkan, "it is clear that one fact stands out in as far as transformational leadership in organizations is concerned that this leadership style induces performance and productivity through reward and punishment". Berdasarkan fakta, Kepemimpinan transformasional dalam organisasi merupakan gaya kepemimpinan yang mampu mendorong kinerja dan produktivitas melalui pemberian penghargaan dan hukuman.

\section{Pengaruh Iklim Kerja terhadap Produktivitas Guru}

Dari hasil pengujiian hipotesis kedua dapat disimpulkan bahwa terdapat pengaruh langsung positif iklim kerja terhadap produktivitas guru dengan nilai koefisien korelasi sebesar 0,993 dan nilai koefisien jalur sebesar 0,434. Ini memberikan makna iklim kerja berpengaruh langsung terhadap produktivitas guru.

Pola hubungan antara kedua variabel ini dinyatakan oleh persamaan regresi $\dot{X}_{3}=120,711+0.101 X_{2}$. Persamaan ini memberikan informasi bahwa setiap perubahan satu unit iklim kerja dapat mengakibatkan terjadinya perubahan produktivitas guru sebesar 0,101 pada konstanta 120,711. Hasil analisis korelasi sederhana iklim kerja terhadap produktivitas guru sangat tinggi, artinya makin baik iklim kerja, maka makin tinggi produktivitas guru. Demikian pula sebaliknya makin buruk iklim kerja maka makin rendah pula produktivitas guru.

Hasil penelitian ini senada dengan pendapat beberapa ahli diantaranya adalah Stringer sebagaimana dikutip Management Sciences for Health (2002:51) menjelaskan bahwa, ". . . work climate influences your behavior at work. A good work climate can improve an individual's work habits, while a poor climate can erode good work habits. Most importantly, a positive work climate leads to and sustains staff motivation and high productivity". Iklim kerja mempengaruhi perilaku seseorang di tempat kerja. Iklim kerja yang baik dapat memperbaiki kebiasaan kerja seseorang, sementara iklim yang buruk dapat mengikis kebiasaan kerja yang baik. Iklim kerja yang positif selalu mengarahkan dan mendukung karyawan untuk memiliki motivasi dan produktivitas yang tinggi.

Selanjutnya Taiwo (2010:300) mengatakan bahwa, "the quality of comfort derivable from work climate determines the level of satisfaction and productivity of workers. 
Workers productivity cannot be optimal, if the conditions of work climate are not favourable. Improved work climate will enhance employee productivity". Kualitas iklim kerja menentukan tingkat kepuasan dan produktivitas karyawan. Produktivitas karyawan tidak bisa optimal, jika kondisi iklim kerja tidak menguntungkan. Perbaikan iklim kerja akan meningkatkan produktifitas karyawan.

\section{Pengaruh Kepemimpinan Transformasional terhadap Iklim Kerja}

Dari hasil pengujiian hipotesis ketiga dapat disimpulkan bahwa terdapat pengaruh langsung positif kepemimpinan transformasional terhadap iklim kerja dengan nilai koefisien korelasi sebesar 0,989 dan nilai koefisien jalur sebesar 0,989. Ini memberikan makna kepemimpinan transformasional berpengaruh langsung terhadap produktivitas guru.

Pola hubungan antara kedua variabel ini dinyatakan oleh persamaan regresi $\dot{X}_{2}=103,977+0,253 X_{1}$. Persamaan ini memberikan informasi bahwa setiap perubahan satu unit kepemimpinan transformasional dapat mengakibatkan terjadinya perubahan iklim kerja sebesar 0,253 pada konstanta 103,977. Hasil analisis korelasi sederhana kepemimpinan transformasional terhadap iklim kerja sangat tinggi, artinya makin baik kepemimpinan transformasional, maka makin baik iklim kerja. Demikian pula sebaliknya makin rendah kepemimpinan transformasional maka makin buruk pula iklim kerja.

Hasil penelitian ini senada dengan pendapat beberapa ahli diantaranya adalah Makaske (2015:4) dalam penelitiannya menjelaskan bahwa, "here will be a positive relation between positive leadership behavior and work climate and a negative relation between positive leadership behavior and negative work climate. This paper will employ the concept of transformational leadership as positive leadership behavior". Terdapat hubungan positif antara perilaku kepemimpinan positif dan iklim kerja dan hubungan negatif antara perilaku kepemimpinan positif dan iklim kerja negatif. Penelitian ini menggunakan konsep kepemimpinan transformasional sebagai perilaku kepemimpinan positif.

Selanjutnya Abu Orabi (2016:92), menjelaskan bahwa, "the impact of transformational leadership on climate noting that this outcome has systemic implications for employees, customers, and shareholders. Motivated employees working in a supportive climate provide more effective customer service, bolstering organizational performance and leading to financial gains for shareholders". Dampak kepemimpinan transformasional pada iklim mencatat bahwa hasil ini memiliki implikasi sistemik bagi karyawan, pelanggan, dan pemegang saham. Karyawan termotivasi bekerja di iklim yang mendukung menyediakan layanan pelanggan yang lebih efektif, memperkuat kinerja organisasi dan mengarah ke keuntungan finansial bagi pemegang saham.

\section{PENUTUP}

\section{Kesimpulan}

Berdasarkan hasil perhitungan data penelitian dan hasil analisis data yang telah diuraikan, maka dapat diperoleh beberapa kesimpulan sebagai berikut: 1) 
Kepemimpinan transformasional berpengaruh langsung positif terhadap produktivitas guru. Artinya ketepatan dalam kepemimpinan transformasional mengakibatkan peningkatan produktivitas guru SMP Negeri di Kecamatan Palmerah Jakarta Barat. 2) Iklim kerja berpengaruh langsung positif terhadap produktivitas guru. Artinya iklim kerja yang baik mengakibatkan peningkatan produktivitas guru SMP Negeri di Kecamatan Palmerah Jakarta Barat. 3) Kepemimpinan transformasional berpengaruh langsung positif terhadap iklim kerja. Artinya ketepatan dalam kepemimpinan transformasional mengakibatkan terciptanya iklim kerja yang baik pada SMP Negeri di Kecamatan Palmerah Jakarta Barat.

\section{Saran}

Berdasarkan hasil penelitian yang disimpulkan di atas dan dalam upaya meningkatkan produktivitas guru SMP Negeri di Kecamatan Palmerah Jakarta Barat melalui variabel kepemimpinan transformasional dan iklim kerja, dikemukakan beberapa saran sebagai berikut: 1) Bagi kepala Sudin Pendidikan Jakarta Barat perlu memberikan dukungan maupun pembinaan dalam bentuk kebijakan maupun program kepada SMP Negeri di Kecamatan Palmerah pada khususnya yang mengarah pada terciptanya iklim kerja yang baik dan peningkatan produktivitas guru. 2) Bagi kepala sekolah dapat meningkatkan kemampuan kepemimpinan transformasionalnya untuk lebih tepat dan lebih baik lagi dan diharapkan adanya keterlibatan penuh dalam menciptakan iklim kerja yang baik dan kondusif untuk meningkatkan produktivitas guru. 3) Bagi peneliti lain, hasil penelitian ini dapat digunakan sebagai acuan bagi penelitian selanjutnya, terutama yang menguji pengaruh kepemimpinan transformasional dan iklim kerja terhadap produktivitas guru.

\section{DAFTAR RUJUKAN}

Bass, Bernard M. dan Ronald E. Riggio, Transformational Leadership, Second Edition. The United States of America: Lawrence Erlbaum Associates, Inc., 2006.

Colquitt, Jason A., Jeffery A. LePine, dan Michael J. Wesson, Organizational Behavior: Improving Performance and Commitment in the Workplace, Fourth Edition. New York: McGraw-Hill Education, 2013.

Kendrick, John W. dan John B. Kendrick, Personal Productivity: How to Increase Your Satisfaction in Living. New York: Routledge, 2015.

Kinicki dan Kreitner, Organizational Behavior, Third Edition. Mc. Graw-Hill, Inc., 2008. 
McShane, Steven L. dan Mary Ann Von Glinow, Organizational Behavior, Seventh Edition. New York: McGraw-Hill, 2015.

Mulyasa, E., Standar Kompetensi dan Sertifikasi Guru. Bandung: Remaja Rosdakarya, 2008.

Ogbu, Thompson, "School Climate for the Productivity of Secondary School teachers' in Abia State, Nigeria," Journal of Teaching and Learning, (Maiden Edition), Vol.1. N0.1, 2015.

Orabi, Tareq Ghaleb Abu, "The Impact of Transformational Leadership Style on Organizational Performance: Evidence from Jordan", International Journal of Human Resource Studies, Vol. 6, No. 2, ISSN 2162-3058, 2016.

Osagie, Roseline O., "Teacher Development Programs And Teacher Productivity In Secondary Schools In Edo State, Nigeria," The Third Asian Conference on Education, 2011, ISSN: 2186-5892, http://iafor.org/archives/offprints/ace2011-offprints/ACE 2011_0153 .pdf (diakses 04 Maret 2017).

Prokopenko, Joseph, Productivity Management: A Practical Handbook. Geneva: 1987.

Robbins, Stephen P. dan Timothy A. Judge, Organizational Behavior, Fifteenth Edition. The United States of America: Pearson Education, Inc., 2013.

Rodway, Gregory, "How Does Work Climate Affect Performance?", Presentation transcript, https:// brainmass.com/ file / $14740 /$ Climate + of + Performance.ppt (diakses 11 Februari 2017).

Sedarmayanti, Sumber Daya Manusia dan Produktivitas Kerja. Bandung: Mandar Maju, 2009.

Setiawan, Bahar Agus dan Abd. Muhith, Transformational Leadership: Ilustrasi di Bidang Organisasi Pendidikan. Jakarta: Rajawali Pers, 2013.

Sounan, Charles dan Serge Gagnon, Relationships Among Work Climate, Absenteeism, and Salary Insurance in Teaching Hospitals, Original Article, http://journals.sagepub.com/doi/pdf (diakses 11 Februari 2017).

Taiwo, Akinyele Samuel, "The influence of work environment on workers productivity: A case of selected oil and gas industry in Lagos, Nigeria," dalam jurnal African Journal of Business Management, Vol. 4 (3), March 2010, ISSN 1993-8233, http:// www.academicjournals.org/AJBM (diakses 11 Februari 2017).

Wayne K, Hoy, dan Miskel Cecil G., "Educational Administration: Theory, Research, and Practice", dalam Power Points, 2013, http://www.waynekhoy.com/power_points.html (diakses 11 Februari 2017). 